\title{
Reviving the Uhadi: Configuring the Representation and Identity of the Bowstring Musical Instrument in Museum Africa
}

\begin{abstract}
Lindelwa Pepu*
Visual Arts Lecturer at the University of Zululand, South Africa

Article History

Received: 09.10.2020

Accepted: 27.10 .2020

Published: 07.11.2020

Journal homepage:

https://www.easpublisher.com/easjhcs

Abstract: This paper is a formal investigation on how Museum Africa, South Africa preserves, displays and engages musical bows. I analyse the interesting ways the museum has collected, stored and researched the Xhosa Uhadi bow in their collection, from a curatorial perspective. This paper is prompted by the initiative to restore a neglected and forgotten area of musical bows, particularly those that document and encapsulate disappearing traditions and cultural practices. Museum Africa is one of the largest historical museums in South Africa with only a few musical bows. Two curators of the museums participate in this study reporting the Uhadi musical bow purpose in the museum.

Keywords: Uhadi; musical bow; curatorial; revive; preserve; Exhibition.
\end{abstract}

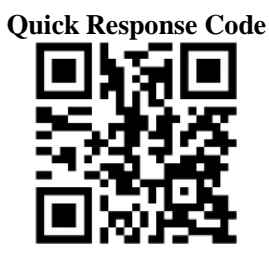

Copyright (C) 2020 The Author(s): This is an open-access article distributed under the terms of the Creative Commons Attribution 4.0 International License (CC BY-NC 4.0) which permits unrestricted use, distribution, and reproduction in any medium for non-commercial use provided the original author and source are credited.

\section{OBJECT BIOGRAPHY}

The Uhadi musical bow is originally from various parts of the Eastern Cape where remarkably similar bow instruments such as istolotolo (harp) and umrhubhe (mouth piece) are found amongst the Xhosa people. Consistent findings of numerous research investigations have demonstrated that just as most bows the uhadi musical bow was developed from the hunting bow of the Khoisan people. It was first made from a specific indigenous tree only found in the Eastern Cape but is now made from any wood. The wood is according to female Uhadi player, Mthwakazi Lenga [1] is left to dry for a couple of days before combining it with the string and the resonator gourd that when cut open, the seeds are removed and kept for planting and growing the gourd continuously. The brown natural colour of the wood occurs when left to dry and when used for a while the colour becomes stronger. The string is fastened on each end of the curved wood not too firmly so it is flexible to move. This is an instrument specifically known to be played by women during the day or special occasions and is usually accompanied with the voice in singing or humming that correlates with the beat being played for an intriguing performance to watch.

\section{INTRODUCTION}

In South Africa the Uhadi bow is commonly associated with isiXhosa culture. The instrument can be found in museums such as Museum Africa ${ }^{1}$ in Johannesburg South Africa. Museum Africa is an art, culture and heritage institution with the primary focus of preserving and conserving South Africa's cultural and historical heritage. The museum has an extensive collection, which consists of a number of musical bows in which one is the Uhadi as part of the permanent collection and many more that feature in the photography collection. The instrument has been described in the museum's collection management system in two different ways. Firstly, in the photographic archive which is part of the museum's collection that is used as alternative reference to what the museum has exhibited or collected.

It has been labeled as a 'utensil or craft'. According to Michael Nixon's investigation [2] labeling the instrument as a utensil appears to come from the fact that the gourd is used as a water or beer carrier in the kitchen. This is important to this study in order to understand the conventions of labeling the Uhadi bow in Museum Africa because this kind of labeling gives the impression of the non-existence of the instrument in the museum. Secondly, on the online system the

\footnotetext{
${ }^{1}$ Museum Africa- is known for its collection of African culture and is based in Johannesburg, South Africa.
} 
collection of the musical bows is described: simply as 'musical bow' [3]. The representation of the instrument makes it difficult to locate the actual isiXhosa musical bow. This also contributes to the uncertainty of the musical instrument's origin as they are usually labeled as part of an ethic group as per ethnographic practices in most museums.

In this paper, I examine how the South African bowstring instrument, Uhadi is preserved and revived as a 'traditional' musical bow in a museum. As Cultural theorists, Mieke Bal [4] writes that tradition can be defined in more than one way but is usually conveyed to express a cultural value. In order to explore how museums in South Africa preserve, display and engage musical bows, I analyse, from a curatorial perspective how Museum Africa has collected, stored, exhibited and researched the Uhadi bow in their collection. This study was undertaken as part of a larger master's research project, The Uhadi and Malunga Bow: Curatorial Implication [3]. The study investigated both the Uhadi and Malunga musical bows however, this paper reports data based on the Uhadi musical bow only.

\section{LITERATURE REVIEW}

During the emerging of South African museums research was based on collecting and preserving aesthetic cultural, traditional and African objects with or without sufficient and essential historical background of the items. A writer of the book based on Museum Africa, Sara Byala [5] writes that as the museum was progressing the systematic study of people and cultures grew in importance in that even though they did not know who the actual makers of the objects were, they made it a priority to as least have accurate information and knowledge on their collection by involving the community of people who were culturally experienced and knowledgeable to academic researchers. The collection of traditional musical instruments is an aspect of art that emerged before apartheid times which is why it appears that the labeling was inaccurate. However, sufficient knowledge pertaining to museum objects is usually accessed only in museum space that is why accuracy is important as Mary Nooter Roberts [6] stated that, "the museum as an institution developed in the mid-eighteenth century is an encyclopedia repository for the presentation of knowledge". In addition, Roberts affirms that:

Through a museum's acquisition of an object is generally taken as a proof of the objects value, at the same time, paradoxically, it signifies that the object has decommodified, taken out of the market, and out of time. Transplanted to the synchronic, simultaneous temporal frame of the collection, the object is reclassified. Any specific collection effectively destroys an objects earlier contexts at the same time that is creates a new one [6].
The above states that museums are the primary spaces for any object to be included in its collection; even though its value deteriorates alternative ways must be created to show the importance of the object as part of a museum's collection.

In the book Exhibiting cultures: the poetics and politics of museum display Micheal Baxandall [7] explains that the label does not describe the actual history and background of the object but has an important role of giving the viewer and understanding of what is in sight:

What the label says is not in any normal sense descriptive. It does not cover the visual character of the object. To do so would involve an elaborate use of measurements and geometrical concepts and reference to the representational elements, and would in any case be otiose, since the object is present. The label stands to the object in relation of a different kind, not a descriptive but an explanatory relation.

In my view the conventions behind the labelling of the musical bow as a craft is based on knowledge that the musical bow is made of objects that are hand-made. According to Museum Africa's cultural history curator, Thabo Seshoka, it appears that the labelling of a musical instrument as a craft may have been made by someone with informal knowledge about the origin of musical bows (pers.comm, 2016). It is also possible that this labelling was created just to add and identify such an instrument within the museum archival system.

The idea of focusing on preserving and reviving the musical bow in a museum as a performance instrument is based on the curatorial as a concept. Curatorial is a concept that comes from curatorship. Which according to Erica Lehrer, Cynthia Milton and Monica Patterson [8] is: Taking the word "curate" in its root meaning of "caring for" allows us to expand our discussion outward from museums and exhibitions to encompass heritage sites, memorials, and other (including virtual) locations along the increasingly interlinked spectrum of spaces dedicated to connecting publics with difficult histories - anywhere that attempts are made to "[present] combinations of images, objects, text, and sound within a particular mise-en-scene," ... This is to say that to "care for" the past is to make some-thing of it, to place and order it in a meaningful way in the present rather than to abandon it. "

The above simply defines the ability for any instrument such as the Uhadi bow to have optional platforms to be recognized and acknowledged by different audiences. Thus, curator Eszter Szakacs [9]:

Curatorial work no longer concerns solely the display of artworks and the task of exhibition- 
making; it is now also understood as a practice centered on longer, term less object-orientated, discursive-educational projects that involve various people as instigators and actors (discursivity-collaboration-participationeducational turn-performativity).

In other words, curatorial work is a practice that is about the people who are the creatives of the various projects then just artworks and exhibitions. Therefore, the musical bows that exist in museums should be attributed and labelled with the makers.

However, because the instrument is not attributed to a maker in Museum Africa; this then raises the question: why are museums collecting objects or instruments without the maker's name? This may be one of the reasons it is seen as a disappearing species because the makers are untraceable for those interested in learning or buying traditional instruments. Furthermore, Baxandall [7] states the importance of the attribution of the maker.

The first agent, and clearly a very necessary one, is the maker of the artifact. If one thinks of the maker's relation to his culture in terms of the customary distinction between a participant's understanding and an observer's understanding, the maker is the classic participant. He understands his culture more immediately and spontaneously than outsiders (exhibitor or viewer included). Baxandall highlights an important point that can help the viewer relate to the maker's cultural understand and belonging, creating platform for the maker to be acknowledged for their creation.

The other curatorial strategy is through exhibiting musical bows regularly and frequently for better conserving, preserving and revival of the instrument in a museum. As such, in relation to musical bows, "objects are presented in vitrines, on stands, or on walls and are accompanied by labels, leaflets, or catalogue" [7]. Therefore, Museum Africa can consider alternative ways such as regular thematic exhibitions of such instruments as well as representing the bow musical instruments in vitrines and stands with an attempt of giving the instruments a platform in the museum where the makers of a particular musical bow instrument are acknowledged.

\section{Statement of Problem}

Generally, museums collecting musical instruments including Benoni Museum in Johannesburg, the Kirby Collection in Cape Town, and the International Library of African Music in Grahamstown; usually label musical bows according to their ethnic group. This in turn defines, classifies and limits the way we understand the objects. In this case, the ethnicity as a label makes visible the people within a society that perform this particular instrument. This has been the primary concern for museum labeling of indigenous items. For example, in a sketch of an Uhadi player in the Museum Africa Photography Collection, the caption "gubo" refers to the Zulu word for musical bow "ugubu". However, in Museum Africa's accompanying notes in the bottom right hand corner of the image it is classified as "Xhosa".

My sense is that there is something problematic about the ways in which museums, in general and Museum Africa in particular, have collected, stored and displayed indigenous instruments. For instance, they are often mislabeled, decontextualized, and under-researched, in need of conservation and not often exhibited. While museums are commonly understood as spaces that 'preserve' history, these objects only appear to be part of the collection but are in many ways forgotten. Thus, in most museum collections, objects such as these often have no individual makers' or performers' acknowledged or attributed. Museums have thus prioritized establishing an ethnic group rather than the individuals who make and play the instruments, thereby rendering makers and performers invisible and silent. In the literature review I detail some of the possible reasons for why makers are unknown and how it is not regarded relevant information in most museum resources and the function of an ethnography collection within museums such as Museum Africa. While Museum Africa's photographic collection referencing the Uhadi shows people playing the instrument, none of them are named individuals and none of them are women. This is odd, since the Uhadi is generally known as an instrument that is played by women, though it was first made my men.

In order to explore how museums in South Africa preserve, display and engage musical bows, I analyze, from a curatorial perspective how Museum Africa has collected, stored, exhibited and researched the Uhadi bow in their collection. My primary research question is: how has the collection and display of historical musical bows in South Africa limited our understanding of the tradition and prevented possible revival? Secondary questions include: what alternative curatorial strategies might there be for musical instruments such as the Uhadi?

\section{METHOD \\ Participants}

This particular focus of my study did not have a large number of participants because the investigation was based on one museum, Museum Africa, which has minimal employees and is the largest heritage museum in the country. As such, there were on two participants involved. The objects and photography curators of Museum Africa. One curator assisted with searching for the object on the online system as well as handling the 
Uhadi in the storeroom. While, the other curator assisted with accessing the images as well as written information based on the Uhadi musical bow.

\section{Procedures}

After management consent from the appropriate administrative bodies of the museum it was the curator's consensus required for the interviews to be conducted. Thereafter, the curators were contacted in writing via email, invited to participate in the study. Face-to-face interviews were conducted at the museum with the two main curators. Voice recording was a method of collecting data needed which was transcribed into writing as part of the research based on the knowledge each curator had on the Uhadi musical bow found in Museum Africa collection.

The interviews were based on understanding the knowledge of current Museum Africa's curators with regards to the history of the museum and the rationale of the way the institution functions.

To begin, I Interviewed $\mathrm{Mr}$ Kenneth Hlungwani who is the current photography curator who collects and preserves photography of any item that comes into the museum either for display or permanent collection. Mr Hlungwani revealed that the Uhadi musical bow is labelled and represent as a 'utensil or craft'. He was unable to clarify the reason behind this labelling because the musical bow was collected before he came in and was labelled but a curator who was unknowledgeable about museum collections.

Hlungwani [10] stated that "photography of the items occurs if the items are borrowed and to be displayed at the museum for a certain period. This helped with identifying the items easily and keeps them in a good condition". While, Thabo Seshoka is the museums Cultural history curator who engages more with the museum storeroom collection with regards to the various items that are from different cultures as well as the oldest and latest collections received by the museum [11]. I then questioned him on his knowledge based on the musical bows that feature in the museums storeroom. Mr Seshoka was able to identify the Uhadi bow within the collection after having difficulties finding it on the museum system because the system was not updated in the last 20 years [12]. The labelling on the online system made it difficult to identify the different bows because they were simply labelled as musicals bows with no ethnical classification.

\section{RESULTS AND DISCUSSIONS}

The outcome is that the musical instrument is indeed preserved, collected, decontextualized and neglected by the museum. The Uhadi bow is labelled inaccurately and is never displayed to the public which is why it is not known for its significant value and existence in the museum. The museum also appears to have a non-unified staff that is not aware of everything happening in the museum and especially of the museums history which is revealed. it is clear that the museum needs to articulate ways that will show the importance of having such instruments in order to be learnt about by future generations.

\section{LIMITATIONS}

This study is limited in several ways. Museum Africa does not have sufficient information on the Uhadi musical bow and knowledgeable curators on the history of the museum collection. As the largest historical museum, it did not have sufficient musical bows as anticipated and the way the instruments are collected, preserved delayed the ability to trace the musical bow in the museum collection. The 20-year non-employment gap has had an impact on understanding the museum collection history and researched information.

\section{CONCLUSION}

The main objectives of this study were to explore the curatorial implications that have an impact on the revival of the Uhadi bow collected by Museum Africa. This study revealed some aspects of the museum that have led to the decontexalization, preserving and storing of the Uhadi musical bow. The extremely large gap for employing needed and relevant staff has impacted on the way the instrument is represent in the museum. The research that exists in the museum is limited and was discovered by previous employees not particularly qualified to work in a museum and having limited resources to capture. It appears that even if the photographic museum collection correlates to locating the actual instrument within the collection, the photography curator and object curator do not co-operate with each other and understanding the history of previously captured museum collection.

\section{About The Author \\ Lindelwa Pepu is currently a Visual Arts Lecturer at the University of. Zululand, South Africa. She has the interest to advocate for artists, being (the- voice-of-the-voiceless), particularly revealing the artist as not only the creative but a professional. My research is usually based around curatorial practice and Art history.}

\section{REFERENCES}

1. Lenga M. (2017). Interview with Uhadi female player on 22 February 2017.

2. Nixon, M. (2016). Interviewed by Lindelwa Pepu on email.8 December 2016.

3. Pepu, L. (2018). The Uhadi and Malunga Bow: Curatorial Implications (Master's dissertation).

4. Bal, M. (1964). Traveling concepts in the humanities: a rough guide/Meike Bal. University of Toranto Press, c2002. Toranto. 
5. Byala, S. (2013). A Place that Matters Yet: John Gubbins's MuseumAfrica in the Postcolonial World. Chicago and London: The University of Chicago Press.

6. Roberts, N. M., Vogel, S., \& Müller, C. (1994). Exhibition-ism: museums and museum display. Smithsonian Institution Press: Washington and London.

7. Baxandall, M. (1991). Exhibiting intention: Some preconditions of the visual display of culturally purposeful objects. Exhibiting cultures: The poetics and politics of museum display.

8. Lehrer, E., Milton, C., \& Patterson, M (Eds). (2011). Curating Difficult Knowledge: Violent Pasts in Public Places. Palgave Macmillan Memory Studies. Palgrave Macmillan, London.
9. Szakacs, E. (2012). Curatorial Dictionary. Available at: http://transit.orrg/curatorialdictionary/index.php/ab out/.

10. Hlungwani, K. (2016). Interview with Photography Curator on 14 December 2016. Johannesburg. Cell phone voice recorder in possession of L. Pepu.

11. Seshoko, T. (2017). Interview with Cultural History Curator on 27 January 2017. Johannesburg. Cell phone Voice Recorder in possession of L. Pepu.

12. Uhadi-TraditionalInstrument.Online.URL: https://www.geocaching.com/geocache/GC5NEQ N_uhadi-traditional-instrument?guid=e03ba1e4560c-42dd-be9c-3acebf50234a. 